Scientific Journal Warsaw University of Life Sciences - SGGW

Problems of World Agriculture volume 17 (XXXII), number 4, 2017: 263-270

DOI: $10.22630 /$ PRS.2017.17.4.102

\author{
Piotr Pomichowski \\ Warsaw University of Life Sciences - SGGW
}

\title{
Comparison of Poland's Agrarian Structure with other EU Countries Using Cluster Analysis
}

\begin{abstract}
The analysis of agrarian structure of agricultural holdings in Poland was carried out in comparison with other EU countries. The study was conducted on the 2005 and 2013 data derived from Eurostat databases by means of cluster analysis. The results of the analysis confirmed the hypothesis of improvement of the agrarian structure of agricultural holdings in Poland vis-a-vis other EU countries. An increase in the average farm size was observed with a decrease in the number of entities.
\end{abstract}

Keywords: agricultural holdings problems, farm fragmentation, agrarian structure, cluster analysis

JEL Classification: Q15, C10, C38

\section{Introduction}

Farms which are primarily located in rural areas are of great economic, social and environmental importance. They form an agricultural sector which plays a significant role in Poland's national economy as well as in other European Union countries. This sector provides jobs for many people who produce food and other materials used in industry. The transformation and development of a sector as strategic as agriculture, requires cooperation and balance between social and economic factors. Disturbance of any of these factors can cause problems for agricultural producers. Correct diagnosis and adaptation to programs supporting agricultural development can mitigate the effects of these disturbances. It should be noted that the economic environment and changing reality in which farms operate require adaptation to new conditions, which agriculture a more evolutionary character.

One of the main problems of agricultural holdings in Poland is their fragmentation which results in an unfavourable agrarian structure. This means that a significant number of these holdings have little chance of development and the agricultural sector cannot fully compete with other EU countries. This situation is closely linked to the number of people employed in the agricultural sector and to the level of education of the rural population. These aspects were widely discussed and put forward in the work of Piotr Prus "Contemporary Problems of Agriculture and Rural Areas". His study focused on the problem of Poland's agrarian structure in relation to other EU countries. In order to analyze the problem of the paper, the following hypotheses were made:

- the average size of agricultural holdings in Poland increased and their number decreased,

\footnotetext{
${ }^{1}$ MSc, Department of Agricultural Economics and International Economic Relations, Faculty of Economic Sciences WULS - SGGW, ul. Nowoursynowska 166,02-787 Warszawa, e-mail: piotr_pomichowski@sggw.pl, https://orcid.org/0000-0001-6466-332X
} 
- the improvement of Poland's agrarian structure against other EU countries was observed.

In order to verify the questions posed, a literature review was done and the study was conducted. The appropriate conclusions were drawn.

\section{Literature review}

Agriculture is one of the most important economic sectors influencing the standard of living and the economic and social development in rural areas. Although the share of this sector in GDP is constantly decreasing, it still creates jobs for more than half of the rural population ${ }^{2}$, which accounts for $10.5 \%{ }^{3}$ of total employment (Q2 2017). The farm is the basic economic unit of the agricultural sector and creates a socio-economic system. Its primary function is to meet the needs of the farm's owner and his family members who depend on the income generated by whatever is produced. The factors influencing the amount of income earned from running a farm can be endogenous and exogenous. The first group includes factors which are influenced by the farmers themselves, e.g. the size and the way of using the factors of production (capital, land, labor). The second group includes factors on which the farmers have no impact (they are linked to external conditions) e.g. prices of agricultural products and goods or weather conditions (Gardner, 1990; Rembisz, 2006). Therefore one of the determinants of production is the agricultural holding size. The literature includes a number of papers devoted to the problem of fragmentation of Polish farms. This phenomenon is the subject of a lively debate because of its negative impact on the efficiency of farming which ultimately affects the competitiveness of the agricultural sector against other EU countries. Reduction of this phenomenon should significantly contribute to the improvement of agrarian structure which, in turn, may result in more efficient use of production resources (Gozs, Kozera, 2002; Jackson-Smith, 1999).

In the paper "Contemporary Problems of Agriculture and Rural Areas" (Prus 2008), the author identified the problems occurring in agriculture and made a thorough analysis. He pointed out that the income situation, the level of education and the stock of labor in the agricultural sector could significantly contribute to the current situation in this sector. When describing the income situation of farms, he underlined the past significant disparities between agricultural income per capita and the average net income for farms up to 50 ha. He emphasized a significant increase of income from non-agricultural sources such as pensions or paid work in total household income. The decline in agricultural income and the increase in differentiation of earnings levels, led to a rise of pessimistic assessment of agricultural holdings economic development. According to Gutkowska (2002), for this reason the majority of farmers considered their farms to be non-expandable which contributed to a lack of investments or their enlargements. Another interesting problem described by Prus was the issue of low education among the farm owners. The author pointed out that the human factor and its quality significantly contributed to achievement of competitive advantage on the market, and its low quality among the owners of Polish farms constituted a barrier for farm development.

\footnotetext{
${ }^{2}$ According to the "National Strategic Plan for Rural Development" from 2005, 66\% of the rural population was employed in the agricultural sector.

${ }^{3}$ The data come from the website http://rynekpracy.org/x/989321.
} 
As a consequence, the low level of education among farmers contributed to their reduced socio-occupational activity which in turn led to bigger difficulties in finding an alternative, better paying jobs. In addition, the author emphasized that knowledge could determine the existence of entrepreneurial attitudes which may, in turn, affect the efficiency and productivity of agricultural production. Additionally, low education contributed to the increase of agriculture labor resources leading to so-called agrarian unemployment. The author rightly noted that the high level of employment in agriculture was inextricably linked to the fragmentation of farms that in the future may result in the poor agrarian structures. For comparison purposes, the author used the average farm size which in Poland according to the "Rural Development Program 2007-2013", was 10 hectares, while in the EU-15 it was about 23.11 hectares $^{4}$. Such fragmentation prevented accumulation of capital and other production resources what would enable increased investment and improved management effectiveness. As a consequence, this would contribute to the increase of the agricultural sector competitiveness in comparison with other EU countries and to the increase of the net agricultural income per person employed in agriculture.

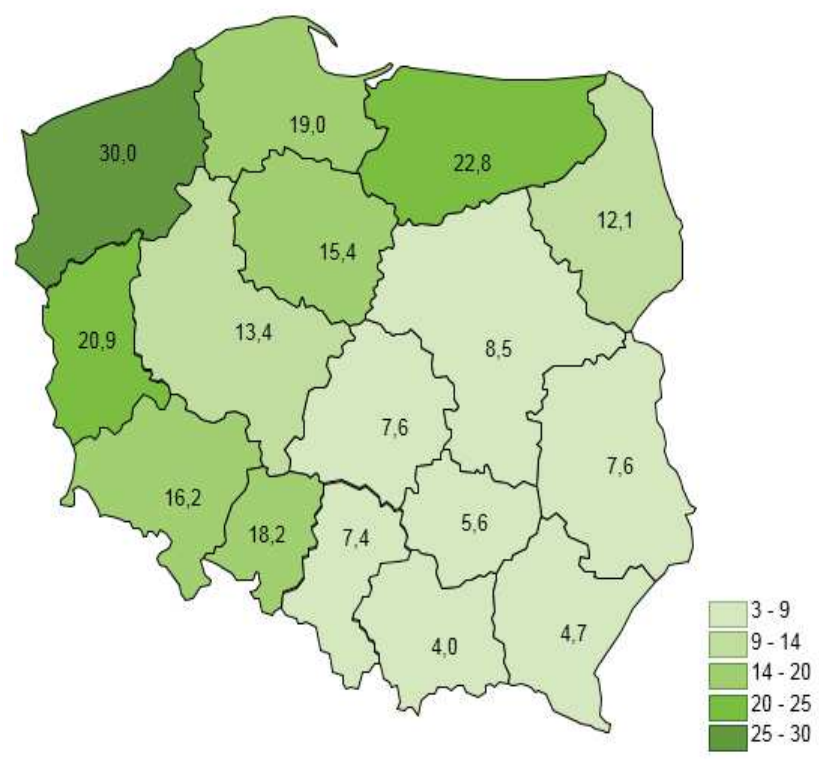

Fig. 1. Average size of agricultural land in the farm by voivodeships, 2015 (hectares)

Source: ARMA (the Agency for Restructuring and Modernisation of Agriculture).

The author considers that the present situation of the agricultural sector is largely the result of a systemic transformation at the turn of the 1980s - 1990s. It covered the entire economy and affected the behavior of all economic entities. In addition, the crisis and

\footnotetext{
${ }^{4}$ The author also noted the considerable diversity within the country, where the largest average farm area (20 ha) is in the north-western regions, while the smallest (3.3 ha) in the south. For the EU countries, the largest is UK at 70 ha and smallest is Italy with 8 ha.
} 
downturn in the whole economy, as well as in agriculture, and the lack of support from the state contributed to the weakening of modernization processes in agricultural holdings. All this led to an increase in disproportions to other sectors of the economy and deepened the problem remaining after the centrally planned economy: improper structure and spatial development. Particularly, along with the changes, state intervention in the market and the instruments of agricultural policy used up to that time, were reduced to a minimum. Such a policy allowed control of prices by controlling the demand and supply or setting prices for agricultural products and means of production at a relatively low level. The deterioration of the general situation in the country (as a result of liquidation of state enterprises), the emergence of unemployment and the rise in prices of agricultural products reduced the demand for domestic food and caused the difficulties in selling it. Therefore, it had a great impact on the economic situation of many farms. The highly profitable agricultural production guaranteed by the state collapsed.

A detailed analysis of changes in the number of farms in Poland was conducted by Jan Falkowski and outlined in his article "Change in the Number of Agricultural Holdings in Poland during the Period of Transformation" (Falkowski, 2010). In this work he raised the issue of the unfavourable impact of the fragmentation of agricultural holdings on the efficiency and productivity of the agricultural sector. In addition, he claimed that owning a farm was a kind of social security for the inhabitants of the rural areas and that the change in the number of farms should be connected with the problem of rural depopulation. In his work, he created an econometric model based on the data on the change in the number of farms in the counties (explanatory variable) in the years 1996-2002, whose purpose was to examine the influence of various factors on the explanatory variable. According to his analysis, the number of farms in the counties was bigger mainly where the small farms dominated. This argument was supported by the fact that it was easier for the larger farms to survive in the free market economy. In turn, the slow fall in the number of farms, according to the results obtained by the author, depended on the agricultural labor force. According to the literature, higher employment in agriculture indicates that there is no alternative employment in other sectors of the economy in the region, so abandoning a farm is associated with an increased risk of unemployment. The results of the model indicated that, contrary to popular beliefs, a larger decrease in the number of farms was observed for poviats where development prospects were positively assessed by the farm owners. The author explains this result as a consequence of extremely high competition and overoptimistic development forecasts. Similarly, in poviats where the population inflows to rural areas increased, the rate of decline in the number of holdings increased. According to the author's analysis, as a result of systemic transformation in years 1996-2002, about 1.2 million entities resigned from agricultural production. Falkowski's study is full of interesting information which can help in explaining the causes of area structure differences between Poland and other countries.

The agrarian structure of agricultural holdings in the European Union is very diverse. Jerzy Babiak in his article "Changes in Agricultural Structure in Countries of the European Union" (Babiak, 2010), writes that this is caused by natural factors and structural transformations and the tendencies of these changes are heading towards decrease in farm numbers and the area extension of the existing ones. According to the author, this is due to well-designed institutional tools for controlling and directing agricultural land turnover. An analysis of the structure of agricultural holdings between 1979 and 2007 indicated that in most European countries (EU-15) the number of farms increased in the area of over 50 ha. 
Among the countries which entered the European Union after 2004, the largest number of farms are in Romania and Poland ${ }^{5}$. This is because of the predominance of small farms covering up to 5 hectares. Over time their number decreased and therefore the average area of the farm increased. The author mentioned that the process of transformation in the agrarian structure took place in two stages. The first began after World War II and the main drivers of the changes were the mechanisms of market competition and economic factors. The second stage was launched in the early 1960s and can be still observed today, where both the changes and their pace were stimulated by governments and EU policies under the CAP $^{6}$.

Later in this paper the area of agricultural holdings in Poland in comparison with other EU countries will be analyzed.

\section{Data and research methodology}

Based on the above literature review, the data provided by Eurostat were used to compare the agrarian structure of agricultural holdings in Poland against other EU countries. The data collected from the website included the number of farms and the total agricultural land size for each EU country. The number of agricultural holdings, described in the statistics included farms recognized both as individual and legal entities. Available data considered years 2005, 2007, 2010 and 2013, while only 2005 and 2013 data were used for comparative analysis. In addition, a new variable representing the average farm size in a given region was created which was obtained by dividing the amount of utilised agricultural land by the number of farms.

The method of cluster analysis was used to verify the hypothesis. It classifies objects according to the degree of their similarity by selected features. The work "Evaluation of Human Capital in Selected EU Countries Using Cluster Analysis" (Parlińska, Pomichowski, 2016 ) is an interesting study describing the application of this method. The optimal number of clusters is determined arbitrarily or by using already formulated indices. One of them is the Caliński-Harabas index which was published in 1974 in the article "A Dendrite Method for Cluster Analysis" (Caliński, Harabasz, 1974). It takes the maximum value for the optimal number of clusters. For the purposes of this article, the number of clusters is set at 3, referring to the EU Member States accession order:

- countries of so-called "Old EU", i.e. EU-15,

- countries that entered the EU in 2004,

- countries that joined the EU after 2004 - in 2007 and 2013.

As already mentioned, the purpose of cluster analysis is to isolate homogeneous groups consisting of similar elements in terms of selected features. For this purpose many algorithms are used. The most popular one due to its low computational complexity is the $\mathrm{k}$-means method. It requires declaring the initial set of clusters and it is very sensitive to outliers. It is about algebraic designation of the so-called centroid, or "center of group's gravity" which does not belong to the grouping elements. Then the grouping is done until the next grouping does not improve the criterion function. This function determines whether the next grouping is better than the previous one. The example of such a function

\footnotetext{
${ }^{5}$ The findings were described on the basis of data for 2007

${ }^{6}$ Common Agricultural Policy.
} 
is, among others, the average distance of the group elements from the center of the group's gravity. The analysis was performed in the R program using the "cluster" packages.

\section{Results}

Cluster analysis was carried out on data for the 27 EU Member States from 2005 and 2013. On the basis of the results it can be stated that in 2005 (Figure 2) Romania had the most unfavorable ratio of farms number (vertical axis) to their average size (horizontal axis). There were more than 4 million farms with an average area of less than 5 hectares (3.27 ha). According to the grouping analysis, Romania, together with Poland, created a two-part group that differed from other EU countries in terms of agrarian structure. Poland at that time had over 2.5 million agricultural holdings with an average size of about 6 hectares (5.95 hectares). The second group comprised, among others, countries such as Italy, Spain, and France, which had a lower numbers of farms and their average area was higher than in Poland. The best agrarian structure in this group of countries was observed in Spain and France. The number of farms amounted to respectively ca. 1 million and 0.57 million and the average size was more than 20 hectares and 40 hectares. The other countries that entered this group were Greece, Hungary and Bulgaria and the average size of the farm did not exceed 10 hectares. The third group was the largest, as it included the other 19 countries. They were different from the other groups due to a smaller number of farms and in most of these countries the average size of the farm was greater than 20 hectares. Agricultural farms in the Czech Republic, where the number of farms was 46,250 and their average size exceeded 80 hectares, had the best agrarian structure.

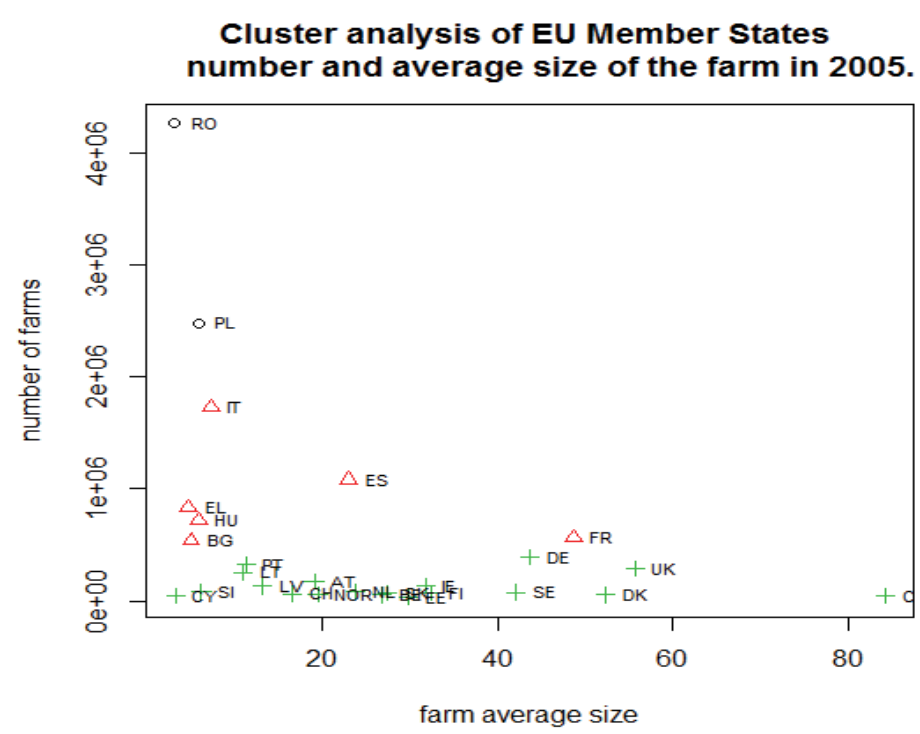

Fig. 2. Cluster analysis results for the $27 \mathrm{EU}$ countries based on 2005 data.

Source: Author's own study. 
Significant improvements in the agrarian structure for all countries can be observed in 2013 (Figure 3). There was a decline in the number of farms with an increase in the average agricultural area size. In terms of agrarian structure Romania created a separate group where the number and average size of farms were respectively 3.63 million and 3.60 hectares.

\section{Cluster analysis of EU Member States number and average size of the farm in 2013.}

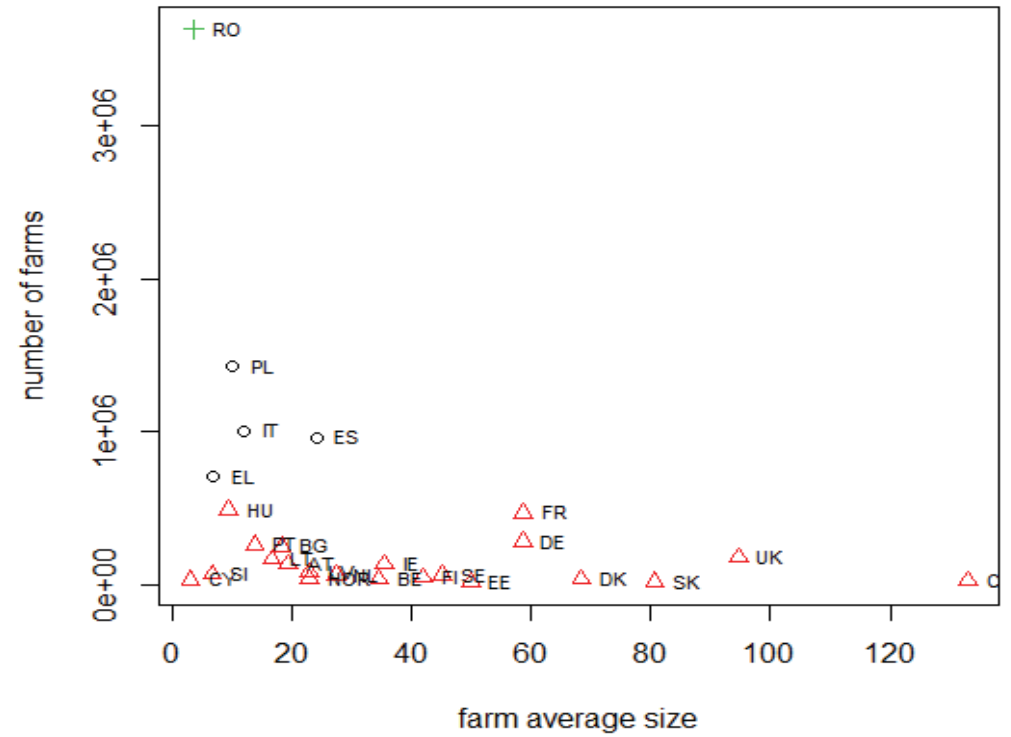

Figure 3. Cluster analysis results for 27 EU countries based on 2013 data.

Source: Author's own study.

Comparing to 2005, the second group changed because of Poland's promotion and exit of such countries as Hungary, Bulgaria and France. It can be assumed that processes improving the agrarian structure of these countries were faster than in other countries from this group. In Poland, there was a sharp decline in the number of farms to 1.43 million and the average size of the farm was 10 hectares. The smallest improvement in the structure of farms was recorded by Spain. The third group represented 22 countries with Hungary, Bulgaria and France joining in 2005. In this group, it seems that for some countries the improvement of agrarian structure is more related to the increase in average farm size than to the decrease in their number. However, the comparison of figures shows a strong negative correlation which means that with the increase in the average area the number of farms decreases (the optical illusion on the graph). For example, in the Czech Republic the average farm size increased from about 85 to over 120 hectares and the number of farms decreased to 26,250. The number of countries with an average farm size of more than 20 hectares also significantly increased. 


\section{Conclusion}

From the above analysis for years 2005 and 2013 it is clear that Poland's agrarian structure significantly improved. The sharp decline in the number of farms resulted in an increase in the average farm size which promoted Poland to a second group of countries. This is probably due to the collapse of low-productivity and low-income farms which resulted in the transfer of production factors to more profitable farms. In addition, one can observe that countries classified to the second group on the basis of the cluster analysis are getting more similar to each other. The graph shows a significant improvement of Poland's agrarian structure in relation to the other countries that constitute the second group, i.e. Italy and Spain. Therefore, the hypothesis stated at the beginning of the paper can be considered right.

\section{Literature}

Babiak, J. (2010). Zmiany w strukturze rolnictwa krajów Unii Europejskiej. Rocznik Integracji Europejskiej, 4 87-97.

Caliński, R.B., Harabasz, J. (1974). A dendrite method for cluster analysis. Communications in Statistics, 3, 1-27.

Falkowski, J. (2010). Zmiany liczby gospodarstw rolnych w Polsce w okresie transformacji. Gospodarka Narodowa, 1-2, 89-108

Gardner, B.L. (1990). The Economics of Agricultural Policy, McGraww-Hill Publishing Company, New York.

Gołaś, Z., Kozera, M. (2002). Strukturalne uwarunkowania wydajności pracy w indywidualnych gospodarstwach rolnych, Zagadnienia Ekonomiki Rolnej, 4, 25-44.

Gutkowska, K. (2002). Funkcjonowanie wiejskich gospodarstw domowych w procesie zmian społecznych na wsi i przewianie przez nie strategie radzenia sobie. In: Samoorganizacja w spolecznościach wiejskich- przejawy struktury - zróżnicowanie, Wieruszewska M. (ed.), IRWiR PAN, Warszawa, 13-23.

Jackson-Smith, D. (1999). Understanding the micro dynamics of farm structural change: Exit, entry, and restructuring among Winsconsin family farmers in the 1980s. Rural Sociology, 64, 66-91.

Kalemba, S. (2014). Przewidywane skutki społeczne, gospodarcze finansowe i prawne - uzupełnienie do uzasadnienia projektu ustawy o kształtowaniu ustroju rolnego złożonego do Marszałka Sejmu w dniu 01.07.2014 r., Warszawa, November $6^{\text {th }}$.

Parlińska, M., Pomichowski, P. (2016). Evaluation of human capital in selected EU countries using cluster analysis. Scientific Journal WUoLS-SGGW Problems of World Agriculture, 16(4), 253-259.

Prus, P. (2008). Współczesne problemy rolnictwa i obszarów wiejskich w Polsce, Katedra Ekonomiki i Doradztwa w Agrobiznesie, Uniwersytet Teologiczno-Przyrodniczy, Bydgoszcz.

Rembisz, W. (2006). Endogenne i egzogenne warunki wzrostu dochodów producentów rolnych, Zagadnienia Ekonomiki Rolnej, 2, 14-30. 